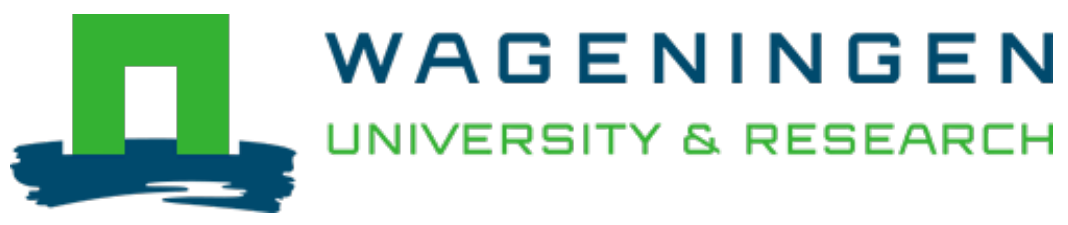

\author{
In vitro digestibility of Bacillus fermented soya bean \\ International Journal of Food Microbiology \\ Kiers, J.L.; Laeken, A.E.A.; Rombouts, F.M.; Nout, M.J.R. \\ https://doi.org/10.1016/S0168-1605(00)00308-1
}

This publication is made publicly available in the institutional repository of Wageningen University and Research, under the terms of article $25 \mathrm{fa}$ of the Dutch Copyright Act, also known as the Amendment Taverne. This has been done with explicit consent by the author.

Article $25 \mathrm{fa}$ states that the author of a short scientific work funded either wholly or partially by Dutch public funds is entitled to make that work publicly available for no consideration following a reasonable period of time after the work was first published, provided that clear reference is made to the source of the first publication of the work.

This publication is distributed under The Association of Universities in the Netherlands (VSNU) 'Article $25 \mathrm{fa}$ implementation' project. In this project research outputs of researchers employed by Dutch Universities that comply with the legal requirements of Article $25 \mathrm{fa}$ of the Dutch Copyright Act are distributed online and free of cost or other barriers in institutional repositories. Research outputs are distributed six months after their first online publication in the original published version and with proper attribution to the source of the original publication.

You are permitted to download and use the publication for personal purposes. All rights remain with the author(s) and / or copyright owner(s) of this work. Any use of the publication or parts of it other than authorised under article $25 \mathrm{fa}$ of the Dutch Copyright act is prohibited. Wageningen University \& Research and the author(s) of this publication shall not be held responsible or liable for any damages resulting from your (re)use of this publication.

For questions regarding the public availability of this publication please contact openscience.library@wur.nl 


\title{
In vitro digestibility of Bacillus fermented soya bean
}

\author{
J.L. Kiers*, A.E.A. Van laeken, F.M. Rombouts, M.J.R. Nout \\ Wageningen University, Agrotechnology and Food Sciences, Laboratory of Food Microbiology, Bomenweg 2, 6700 EV, The Netherlands
}

\begin{abstract}
Bacillus fermented legume products include among others dawadawa and soumbala made from African locust bean, and natto and kinema made from soya bean. Bacillus subtilis is the dominant species involved in the fermentation. During Bacillus fermentation for $48 \mathrm{~h}$ of autoclaved soya bean the quantity of soluble and dialyzable matter increased from $22 \%$ and $6 \%$ up to $65 \%$ and $40 \%$, respectively. Protein and carbohydrate degradation during fermentation of soya bean with several Bacillus spp. was investigated and appeared to be substantial during the first $18 \mathrm{~h}$ of fermentation resulting in the release of high levels of peptides and oligosaccharides. In vitro digestibility was increased from $29 \%$ up to $33-43 \%$ after Bacillus fermentation for $48 \mathrm{~h}$. It was shown that Bacillus spp. were able to degrade soya bean macromolecules to a large extent resulting in water-soluble low molecular weight compounds. In vitro digestion of Bacillus fermented soya bean using gastrointestinal enzymes only slightly increased the amount of dialyzable matter, which clearly demonstrated the beneficial effect of Bacillus fermentation on food nutrient availability. (C) 2000 Elsevier Science B.V. All rights reserved.
\end{abstract}

Keywords: Bacillus; Soya bean; Fermentation; Degradation; Digestibility

\section{Introduction}

Bacillus subtilis is an important starter culture for Asian and African fermented soya bean foods like Japanese natto, Thai thua-nao, Indian kinema and West African dawadawa (Steinkraus, 1995). These fermentations are characterised by extensive hydrolysis of protein to amino acids, peptides and ammonia, and a rise of the $\mathrm{pH}$. Although most indigenous fermented foods are the result of mixed culture

\footnotetext{
*Corresponding author. Tel.: + 31-317-482241; fax: + 31-317484893.

E-mail address: jeroen.kiers@micro.fdsci.wag-ur.nl (J.L. Kiers).
}

fermentation, it has been shown that for kinema Bacillus subtilis is the dominant species (Sarkar et al., 1994).

Dawadawa is generally used as a flavouring agent rather than as a source of dietary protein or calories (Odunfa, 1986), although it is used as a meat substitute by poor families in West Africa (Steinkraus, 1995). However, kinema serves as a major source of protein in the Nepalese diet (Sarkar et al., 1997b). Bacillus fermentation of legumes reportedly resulted in improved digestibility (Odunfa, 1986; Sarkar and Tamang, 1995).

In this study we report the effect of fermentation of soya bean using pure cultures of Bacillus spp. on the solubilization and degradation of soya bean polymeric substances that may result in increased 
digestibility. We used an in vitro digestibility model which has been described and discussed earlier (Kiers et al., 2000).

\section{Materials and methods}

\subsection{Micro-organisms}

Five strains of Bacillus spp. were selected based on their predominance in kinema and soumbala samples: Bacillus subtilis strains B82 and B83 isolated from kinema and B91 isolated from soumbala, Bacillus badius strain B97 isolated from soumbala and Bacillus licheniformis strain B70 isolated from kinema. All isolates belonged to different genotypical clusters based on randomly amplified polymorphic DNA (RAPD) analyses (data not shown).

Bacillus spp. were maintained on nutrient agar slopes (Oxoid CM3). Before use in an experiment the strains were inoculated into brain heart infusion broth (Difco 0037-17) and incubated for $18 \mathrm{~h}$ at $37^{\circ} \mathrm{C}$. The culture was diluted in sterile distilled water with $0.85 \% \mathrm{NaCl}$ and $0.1 \%$ peptone (PPS) to approximately $10^{5}$ colony forming units $(\mathrm{cfu}) / \mathrm{ml}^{-1}$.

\subsection{Fermentation of soya beans}

Dehulled yellow-seeded soya beans (Glycine max) were soaked overnight in tapwater at $4^{\circ} \mathrm{C}$ to avoid fermentative acidification. Soakwater was discarded and the beans were cooked in fresh tapwater for 20 min (ratio beans:water of 1:3), cooled and superficially dried at room temperature. Cooked soya beans $(100 \mathrm{~g})$ were transferred into glass jars and autoclaved at $121^{\circ} \mathrm{C}$ for $30 \mathrm{~min}$, cooled and inoculated with $5 \mathrm{ml}$ of diluted culture. After mixing the beans were fermented at $37^{\circ} \mathrm{C}$ for 24 and $48 \mathrm{~h}$ using the five Bacillus strains separately. A second fermentation series was carried out with Bacillus subtilis B82 and samples were fermented for 6, 12, 18, 24, 36 and $48 \mathrm{~h}$ as described above.

\section{3. pH measurements and microbial analysis}

Samples $(10 \mathrm{~g})$ were homogenised with $90 \mathrm{ml}$ of sterile water. The $\mathrm{pH}$ was measured in this suspension using a glass electrode. Prior to $\mathrm{pH}$ measure- ment decimal dilution series in PPS were prepared and $1 \mathrm{ml}$ of the dilutions was mixed with molten $\left(45^{\circ} \mathrm{C}\right)$ nutrient agar and poured into plates. After solidification a covering layer of nutrient agar was applied and the plates were incubated at $37^{\circ} \mathrm{C}$ for 24 h.

\subsection{Solubility, absorbability and digestibility}

Samples were freeze-dried and ground to a fine flour (Fritsch, type Pulverisette 14, Germany). All samples were defatted by extraction with petroleumether (40:60) in Soxhlet extractors, as this was required for use in the in vitro digestibility model (Kiers et al., 2000). The solvent was evaporated, and quantification of the total crude lipid content (\% of dry weight) was carried out gravimetrically.

Solubility, absorbability and digestibility were determined as described earlier (Kiers et al., 2000). In short, residues obtained after defatting $5 \mathrm{~g}$ of sample were suspended in $30 \mathrm{ml}$ distilled water and incubated for $30 \mathrm{~min}$ at $37^{\circ} \mathrm{C}$. After centrifugation, the dry matter content of the supernatant and pellet was determined and solubility was calculated, representing the percentage of a defatted sample that is water-soluble. Supernatants were dialysed (Medicell Int Ltd, Visking, size 8, cut-off $12-14 \mathrm{kDa}$ ) against running tapwater for $15 \mathrm{~h}$ at $4^{\circ} \mathrm{C}$. Retentates were quantitatively collected and their dry matter content was determined. The percentage of a defatted sample that was able to pass the dialysis membrane was defined as absorbability. Similarly, after solubilization samples were treated with $\alpha$-amylase, pepsin, lipase and pancreatin. Digestibility was defined as the percentage of a defatted sample that was able to pass the dialysis membrane after enzymatic digestion.

\subsection{Electrophoresis}

Sodium dodecyl sulphate-polyacrylamide gel electrophoresis (SDS-PAGE) was performed using a Pharmacia PhastSystem according to the instructions of the manufacturer. To reduce the protein, in order to obtain subunits, disulfide bonds were cleaved by $\beta$-mercaptoethanol. Reduction and solubilization of protein was obtained by head over tail mixing for 90 min and treatment in an ultrasonification bath at $60^{\circ} \mathrm{C}$ for $15 \mathrm{~min}$ twice (Marsman et al., 1997). 
Finally the sample was boiled for $15 \mathrm{~min}$. Runs were performed in Gradient 8-25 Phastgels. Gels were fixed and stained with Coomassie Brilliant Blue R-250.

Since the samples based on autoclaved soya bean could not be separated adequately using this method, we decided to carry out an additional fermentation experiment. In this experiment we did not autoclave the soya beans after cooking as was done for the two other fermentation series. We inoculated the cooked soybeans with Bacillus subtilis B83 as described before and fermented the soya beans at $37^{\circ} \mathrm{C}$ for 24 , 48 and $72 \mathrm{~h}$.

\subsection{Gel permeation chromatography (GPC)}

Molecular weight distribution of the water-soluble dry matter was performed on a LC-10Ai HPLC (Shimadzu) equipped with a Superdex Peptide column (Pharmacia Biotech 17-5003-01) and elution at $30{ }^{\circ} \mathrm{C}$ with $0.1 \%(\mathrm{v} / \mathrm{v})$ trifluoroacetic acid and $30 \%$ (v/v) acetonitrile at $0.5 \mathrm{ml} / \mathrm{min}$. Calibration was performed using a range of proteins and peptides ranging from $7000 \mathrm{Da}$ to $200 \mathrm{Da}$. The eluate was monitored using a UV detector at $200 \mathrm{~nm}$. On the basis of the calibration curve the molecular weight corresponding to various segments of the chromatogram was calculated. The area under the curve was determined in three segments (7000-5200 Da, 5200-1100 Da and 1100-200 Da) and was expressed as the percentage of the total area of the three segments together.
The supernatant obtained after determining the solubility (as described before) of the samples obtained from the second fermentation series was subjected to analysis.

\subsection{High performance size exclusion chromatography (HPSEC)}

High-performance size-exclusion chromatography (HPSEC) was performed on a SP8800 HPLC (Spectra Physics) equipped with three columns (each $300 \times 7.5 \mathrm{~mm}$ ) of Bio-Gel TSK in series (40XL, 30XL and 20XL; Bio-rad Labs) in combination with a TSK guard column $(40 \times 6 \mathrm{~mm})$ and elution at $30^{\circ} \mathrm{C}$ with $0.2 \mathrm{M} \mathrm{NaNO}_{3}$ at $0.8 \mathrm{ml} / \mathrm{min}$. Calibration was performed using dextrans ranging from $500 \mathrm{kDa}$ to $180 \mathrm{Da}$. The eluate was monitored using a refractive index detector.

Approximately $160 \mathrm{mg}$ of defatted samples obtained from the second fermentation series was added to $10 \mathrm{ml} 10 \%$ TCA, mixed, placed for $20 \mathrm{~h}$ at $4^{\circ} \mathrm{C}$ and centrifuged to remove protein and peptides. The supernatant was subjected to analysis.

\section{Results}

\subsection{Growth and $\mathrm{pH}$ changes}

The growth of the Bacillus spp. was rapid during the first 18-24 h (Tables 1 and 2) and exceeded $10^{9}$

Table 1

Colony count, pH, solubility, absorbability and digestibility of Bacillus fermented soya bean ${ }^{\mathrm{a}}$

\begin{tabular}{|c|c|c|c|c|c|c|c|}
\hline Strain & Code & $\begin{array}{l}\text { Time } \\
\text { (h) }\end{array}$ & $\begin{array}{l}\text { Colony count } \\
\left(\log \mathrm{cfu}^{-1}\right)\end{array}$ & $\mathrm{pH}$ & $\begin{array}{l}\text { Solubility } \\
\text { (\% defatted dry matter) }\end{array}$ & $\begin{array}{l}\text { Absorbability } \\
\text { (\% defatted dry matter) }\end{array}$ & $\begin{array}{l}\text { Digestibility } \\
\text { (\% defatted dry matter) }\end{array}$ \\
\hline & & 0 & $3.0^{*}$ & $6.9^{*}$ & $22.3^{*}$ & $6.4^{*}$ & $28.9 * *$ \\
\hline \multirow[t]{2}{*}{ B. licheniformis } & B70 & 24 & 9.4 & 6.5 & 52.1 & 30.7 & ND \\
\hline & & 48 & 9.4 & 7.6 & 54.6 & 32.6 & ND \\
\hline \multirow[t]{2}{*}{ B. subtilis } & B82 & 24 & 9.5 & 7.3 & 59.0 & 31.8 & ND \\
\hline & & 48 & 9.7 & 7.7 & 61.1 & 35.2 & ND \\
\hline \multirow[t]{2}{*}{ B. subtilis } & B83 & 24 & 9.6 & 7.2 & 52.8 & 29.0 & 34.4 \\
\hline & & 48 & 9.9 & 8.2 & 60.4 & 37.0 & 42.8 \\
\hline \multirow[t]{2}{*}{ B. subtilis } & B91 & 24 & 9.8 & 6.7 & 51.2 & 25.5 & 32.6 \\
\hline & & 48 & 9.3 & 7.8 & 61.9 & 35.9 & 37.9 \\
\hline \multirow[t]{2}{*}{ B. badius } & B97 & 24 & 8.8 & 7.4 & 51.5 & 26.9 & 30.9 \\
\hline & & 48 & 9.1 & 8.4 & 64.8 & 39.9 & 34.9 \\
\hline
\end{tabular}

\footnotetext{
${ }^{a}$ Data represent the average of duplicate determinations. * Average of five time duplicate determinations; ** average of three time duplicate determinations; ND not determined.
} 
Table 2

Colony count, $\mathrm{pH}$, solubility, absorbability and digestibility of Bacillus subtilis (B82) fermented soya bean ${ }^{\mathrm{a}}$

\begin{tabular}{llllll}
\hline $\begin{array}{l}\text { Time } \\
(\mathrm{h})\end{array}$ & $\begin{array}{l}\text { Colony count } \\
\left.(\log \mathrm{cfu} \mathrm{g})^{-1}\right)\end{array}$ & $\mathrm{pH}$ & $\begin{array}{l}\text { Solubility } \\
(\% \text { defatted dry matter })\end{array}$ & $\begin{array}{l}\text { Absorbability } \\
(\% \text { defatted dry matter })\end{array}$ & $\begin{array}{l}\text { Digestibility } \\
(\% \text { defatted dry matter })\end{array}$ \\
\hline 0 & 2.9 & 6.9 & 21.1 & 6.5 & 29.5 \\
6 & 6.6 & 7.0 & 20.8 & 6.7 & 27.8 \\
12 & ND & ND & 43.3 & 20.3 & 33.0 \\
18 & 9.2 & 6.8 & 48.0 & 24.7 & 33.2 \\
24 & 9.3 & 7.8 & 52.7 & 25.8 & 29.0 \\
36 & ND & ND & 56.5 & 29.1 & 30.8 \\
48 & 9.7 & 8.3 & 58.5 & 31.4 & 32.6 \\
\hline
\end{tabular}

${ }^{\mathrm{a}}$ Data represent the average of duplicate determinations. ND not determined.

cfu $\mathrm{g}^{-1}$ wet weight after $48 \mathrm{~h}$ fermentation. Although two of the five strains studied, B70 and B91, showed a small decrease in $\mathrm{pH}$ after $24 \mathrm{~h}$ of fermentation compared to time zero, a $\mathrm{pH}$ increase from 6.9 for the cooked and autoclaved beans to 7.6-8.4 after $48 \mathrm{~h}$ of fermentation was observed.

\subsection{Changes in solubility and absorbability}

During fermentation the crude lipid content increased from $28.8 \%$ to $32.7-37.2 \%$ of total dry matter after fermentation for $48 \mathrm{~h}$ (data not shown).

Water-soluble dry matter increased markedly after fermentation for $24 \mathrm{~h}$ and exceeded $50 \%$ of defatted dry matter (Table 1). The highest increase was observed between 6 and $12 \mathrm{~h}$ of fermentation for B82, whereas solubility increased during prolonged fermentation up to about $60 \%$ of total dry matter for all strains studied (Tables 1 and 2). Similarly, the quantity of dialyzable dry matter (absorbability) increased during fermentation. After fermentation $30-40 \%$ of the total defatted dry matter was dialyzable (Tables 1 and 2).

\subsection{Protein degradation}

SDS-PAGE analysis carried out on samples which had been cooked and subsequently autoclaved prior to fermentation resulted in a very poor separation of the soya bean protein subunits. The majority of the protein from the sample obtained at time zero could not diffuse into the gel, although samples obtained after $24 \mathrm{~h}$ of fermentation showed hardly any protein in the top of the gel anymore (data not shown). In Fig. 1 the SDS-PAGE profile is shown for cooked and subsequently fermented soya bean with Bacillus subtilis B83 for 24,48 and $72 \mathrm{~h}$ (lanes 2-5). The major protein subunits can be clearly identified in the cooked soya bean (lane 2). Already after fermentation for $24 \mathrm{~h}$ (lane 3) all protein subunits are degraded to a large extent, and after $72 \mathrm{~h}$ of fermentation virtually all proteins have disappeared (lane 5).

During fermentation of soya bean with Bacillus subtilis B82 the amount of peptides (200-1100 Da)

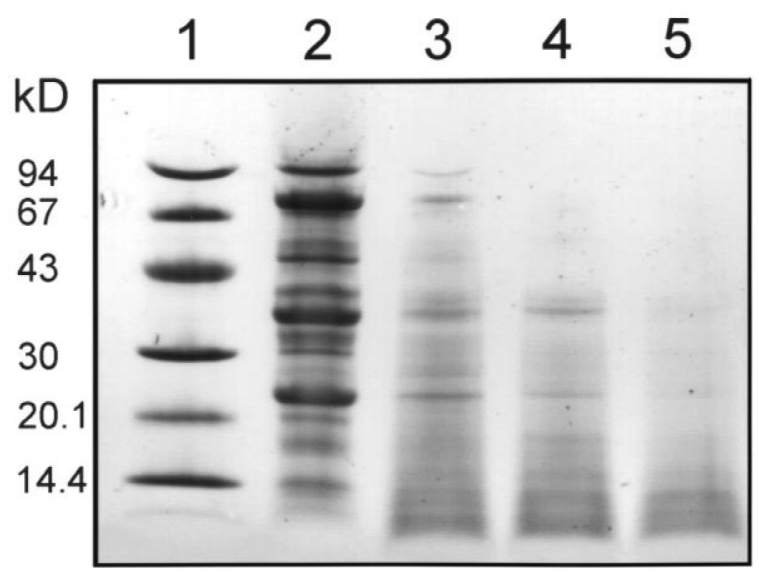

Fig. 1. SDS-PAGE profile of fermented soya bean. In lane 1 markers of several molecular weights are shown. Cooked soya bean fermented with Bacillus subtilis (B83) for 0, 24, 48 and $72 \mathrm{~h}$ is shown in lanes $2-5$. 


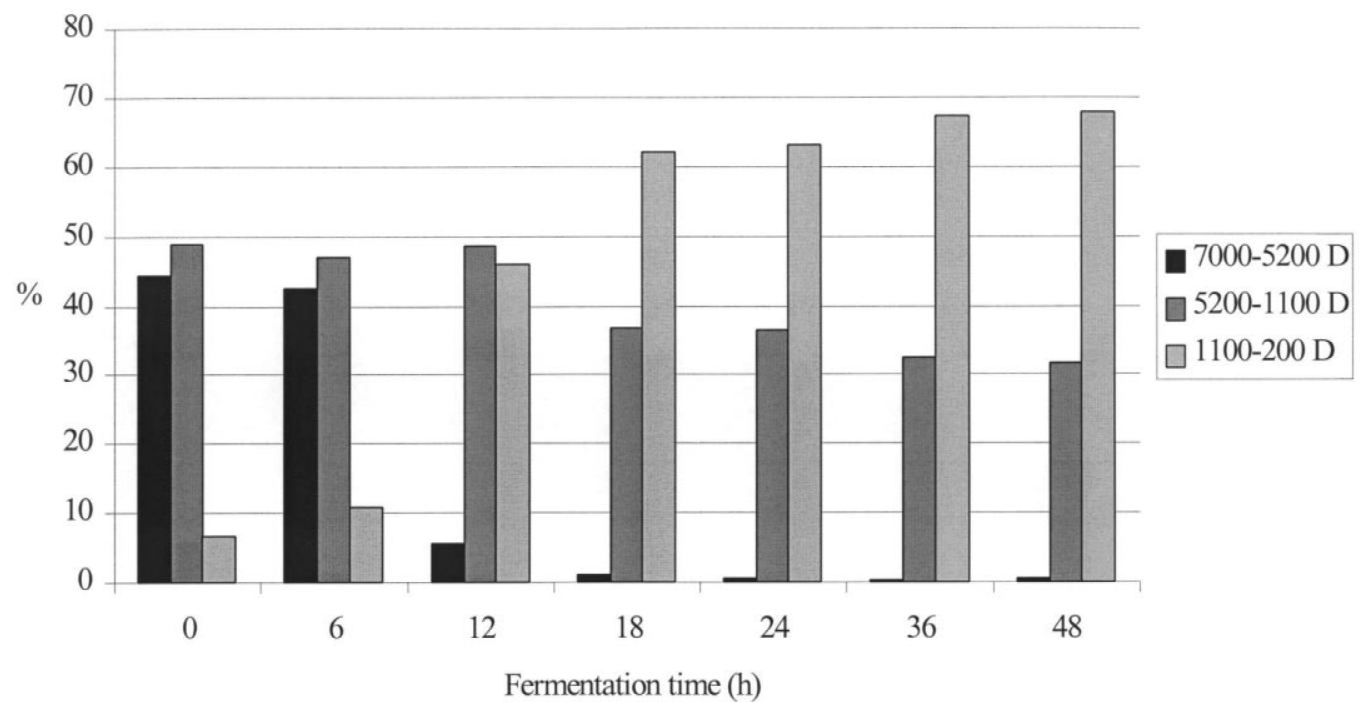

Fig. 2. Molecular weight distribution of water-soluble protein and peptides during Bacillus subtilis (B82) fermentation of soya bean. Bars indicate the percentage of the total (7000-200 Da).

increased markedly at the expense of the protein fraction (5200-7000 Da) (Fig. 2). After $18 \mathrm{~h}$ of fermentation only small changes were observed.

\subsection{Degradation of polysaccharides}

From the dextran standards used it was shown that fermentation of soya bean with Bacillus subtilis B82 resulted in a shift from polymeric to oligomeric matter of $<5 \mathrm{kDa}$ (Fig. 3). Fermentation times over $24 \mathrm{~h}$ resulted in an increased level of intermediate polymeric material from about $500-10 \mathrm{kDa}$.

\subsection{Digestibility}

From Tables 1 and 2 it can be seen that digestibility increased from $29 \%$ of defatted dry matter in cooked and subsequently autoclaved soya beans to $30-40 \%$ in soya beans fermented for $48 \mathrm{~h}$. Compared to the values obtained for absorbability (quantity of dialyzable material without enzymatic degradation) these values are only slightly higher, except for time zero (Table 1) and 0-18 h (Table 2).

\section{Discussion}

\subsection{Changes in $p H$}

The $\mathrm{pH}$ increase observed during fermentation presumably resulted from proteolysis and the release of ammonia due to utilisation of amino acids for growth. The decrease in $\mathrm{pH}$ upon fermentation of soya beans during the first $24 \mathrm{~h}$ with two of the Bacillus spp. used could be due to the ability of these strains to initially use sugars as substrates for growth as shown before (Sarkar et al., 1993).

\subsection{Increase in soluble and dialyzable material}

We ascribe the ability of the Bacillus spp. to solubilize over $50 \%$ of the defatted dry matter to their high enzymatic activity. An increase in watersoluble compounds has been shown earlier for tempe fermentation where solubility increased from $7.0 \%$ for cooked soya bean to maximum of $27.3 \%$ after Rhizopus oryzae fermentation for $24 \mathrm{~h}$ (Kiers et al., 2000).

The increase in absorbability was very likely due to the breakdown of macromolecular substances into 


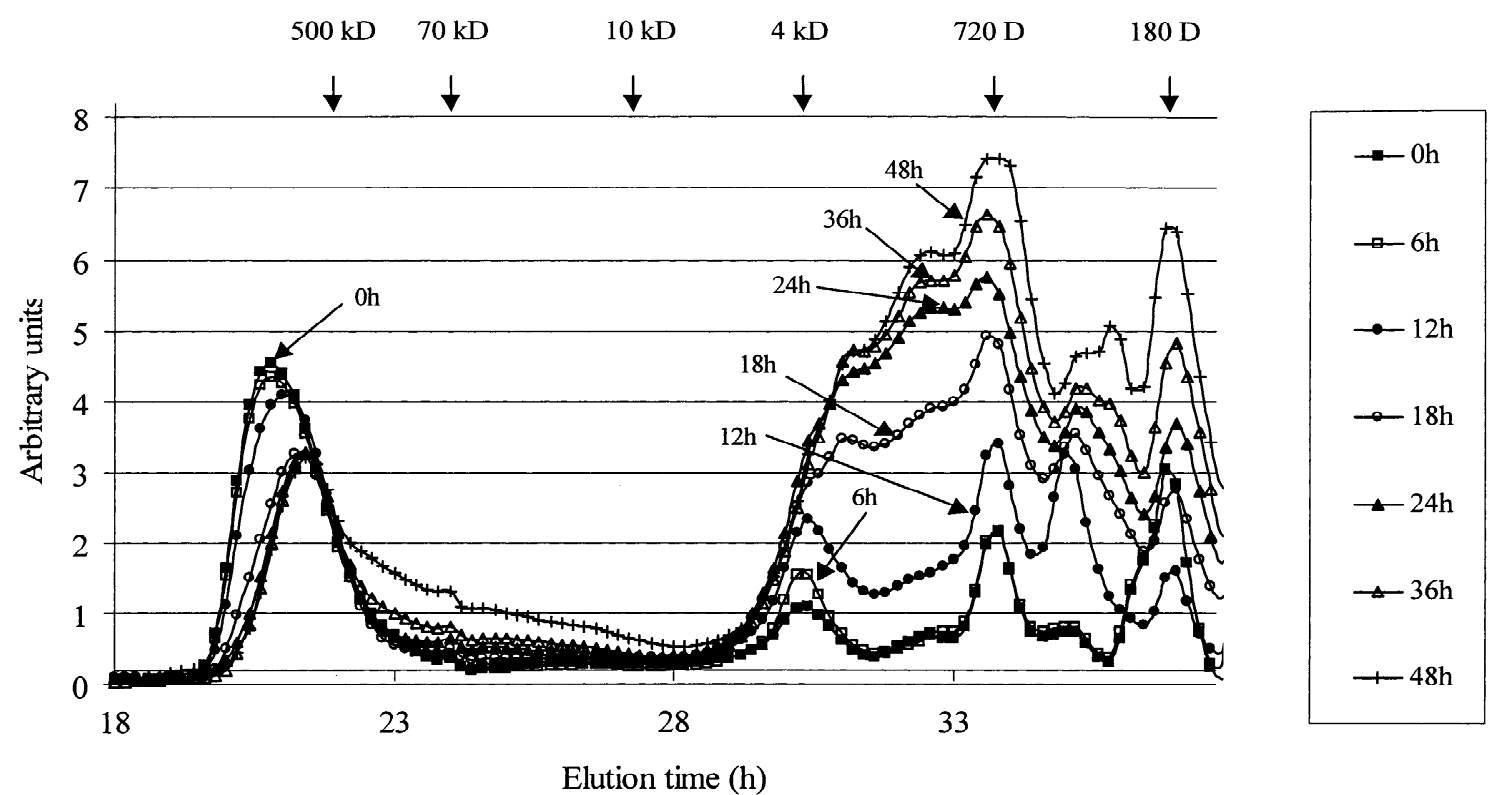

Fig. 3. HPSEC elution pattern of water-soluble carbohydrates during Bacillus subtilis (B82) fermentation of soya bean. Molecular weight of several dextran standards are shown at the top of the figure.

water-soluble low-molecular weight molecules, being small enough to pass the dialysis membrane.

\subsection{Degradation of protein}

Soya beans contain two main storage proteins, $\beta$-conglycinin and glycinin, which are composed of several subunits. $\beta$-conglycinin consists of three components, the $\alpha, \alpha^{\prime}$ and $\beta$ subunit, whereas glycinin consists of an acidic (A) and a basic (B) polypeptide. More or less complete breakdown of all three subunits from $\beta$-conglycinin and both polypeptides from glycinin was observed after Bacillus subtilis (B83) fermentation of cooked soya bean resulting in an accumulation of low molecular weight compounds as shown in Fig. 1. These observations reflect the considerable proteolytic activity reported for Bacillus spp. (Sarkar et al., 1993; Sarkar and Tamang, 1995). Maximum proteolytic activity is reached after 12-24 h and it remains fairly constant during prolonged fermentation (Allagheny et al., 1996; Sarkar et al., 1993). Processing of soya bean with Bacillus subtilis led to a 60-fold increase in free amino acids which accounted for approximately $26 \%$ of the total amino acid content (Sarkar et al., 1997b).

\subsection{Degradation of carbohydrates}

During the first $24 \mathrm{~h}$ of fermentation substantial quantities of polymeric matter were degraded into compounds $<5 \mathrm{kDa}$, whereas during prolonged fermentation also intermediate compounds appeared. Levels of oligosaccharides like raffinose and stachyose responsible for flatus formation resulting from soya bean ingestion are reduced by soaking, cooking and Bacillus fermentation (Sarkar et al., 1997a). No identification of the oligosaccharides liberated during Bacillus fermentation was done in this study.

\subsection{Digestibility}

Bacillus fermentation of legumes has been associated with improvements in digestibility (Odunfa, 1986; Sarkar and Tamang, 1995). Digestibility of fermented soya beans was only slightly increased compared to the cooked and autoclaved beans, whereas absorbability was much higher for fermented soya beans. The same phenomenon was seen during tempe fermentation of cooked soya beans (Kiers et al., 2000), although the values found for absorbability and digestibility were higher in case of Bacillus fermentation. In case of tempe fermentation, 
it was shown from the ratio between absorbability and digestibility that mould fermentation attributed up to $50-60 \%$ of the digestibility (Kiers et al., 2000). In case of Bacillus fermentation this ratio was higher than $80 \%$ after fermentation for $24 \mathrm{~h}$ increasing up to $95 \%$ after fermentation for $48 \mathrm{~h}$. This points to a considerable predigestion during Bacillus fermentation, leading to a product in which luminal gastro-intestinal enzymes hardly can increase nutrient bioavailability.

\section{Conclusion}

Fermentation of soya bean using several Bacillus spp. resulted in major biochemical changes in the substrate leading to an increase in soluble and dialyzable material. Investigations at protein and carbohydrate level revealed major breakdown of polymers into water-soluble low molecular weight peptides, oligosaccharides and monosaccharides. From the results obtained it is concluded that after 18-24 $\mathrm{h}$ of fermentation considerable substrate modification had occurred leading to a product with high nutrient availability in which the need for degradation of nutrients by gastro-intestinal enzymes is minimal.

\section{Acknowledgements}

The authors gratefully acknowledge the support by Numico Research BV, Wageningen, The Netherlands.
The authors also thank C. Prior Pociello for his participation.

\section{References}

Allagheny, N., Obanu, Z.A., Campbell Platt, G., Owens, J.D., 1996. Control of ammonia formation during Bacillus subtilis fermentation of legumes. Int. J. Food. Microbiol. 29, 321-333.

Kiers, J.L., Nout, M.J.R., Rombouts, F.M., 2000. In vitro digestibility of processed and fermented soya bean, cowpea and maize. J. Sci. Food. Agric. 80, 1325-1331.

Marsman, G.J.P., Gruppen, H., Mul, A.J., Voragen, A.G.J., 1997. In vitro accessibility of untreated, toasted, and extruded soybean meals for proteases and carbohydrases. J. Agric. Food. Chem. 45, 4088-4095.

Odunfa, S.A., 1986. Dawadawa. In: Reddy, N.R., Pierson, M.D., Salunkhe, D.K. (Eds.), Legume-based Fermented Foods. CRC Press, Boca Raton, FL, USA, pp. 173-189.

Sarkar, P.K., Tamang, J.P., 1995. Changes in the microbial profile and proximate composition during natural and controlled fermentations of soybeans to produce kinema. Food Microbiol. 12, 317-325.

Sarkar, P.K., Cook, P.E., Owens, J.D., 1993. Bacillus fermentation of soybeans. World J. Microbiol. Biotechnol. 9, 295-299.

Sarkar, P.K., Tamang, J.P., Cook, P.E., Owens, J.D., 1994. Kinema - a traditional soybean fermented food: proximate composition and microflora. Food Microbiol. 11, 47-55.

Sarkar, P.K., Jones, L.J., Craven, G.S., Somerset, S.M., 1997a. Oligosaccharide profiles of soybeans during kinema production. Lett. Appl. Microbiol. 24, 337-339.

Sarkar, P.K., Jones, L.J., Craven, G.S., Somerset, S.M., Palmer, C., 1997b. Amino acid profiles of kinema, a soybean-fermented food. Food Chem. 59, 69-75.

Steinkraus, K.H., 1995. Indigenous fermented foods involving an alkaline fermentation. In: Steinkraus, K.H. (Ed.), Handbook of Indigenous Fermented Foods. Marcel Dekker, New York, USA, pp. 349-362. 